\title{
16. GEOCHEMISTRY OF THE LEG 55 SEDIMENTS
}

\author{
I. O. Murdmaa, V. V. Gordeev, T. G. Kuzmina, and N. V. Turanskaya, \\ P. P. Shirshov Institute of Oceanology, USSR Academy of Sciences, Moscow \\ and \\ G. P. Avdeiko, Institute of Volcanology, Far-East Scientific Center, USSR Academy of Sciences, \\ Petropavlovsk-Kamchatsky
}

\section{INTRODUCTION}

The tops of the Emperor chain guyots, which were drilled during Leg 55, lie above the carbonate compensation depth (CCD), as well as above the foraminiferal dissolution level, i.e., lysocline. They are therefore the sites of accumulation of pelagic foraminiferal nannofossil ooze, such accumulation having taken place here since the moment of the seamounts' subsidence and the termination of shallow-water carbonate accumulation which was formerly developed on their tops. But the existence of strong bottom currents over the tops and slope scarps limits, and at some places reduces to zero, sedimentation of any pelagic particles. At such areas there are formed thick iron-manganese crusts. The seamounts drilled on Leg 55 are within the northern (Boreal) belt of biogenic silica accumulation, which existed in the northern Pacific throughout the Neogene. This circumstance presupposes a possible enrichment of the relatively fine-grained sediments with biogenic silica - diatoms and radiolarians.

The sediment specimens, which have been sampled by the Leg 55 participants and kindly handed over to us for geochemical studies, reflect all of the above three cases. At Site 433 on Suiko guyot, the drilling recovered a section of pelagic siliceous-calcareous oozes underlain by shallow-water benthogenic-detrital (reef) calcareous sediments. The cores recovered on Ōjin guyot (Site 430) and on the seamount north of the Nintoku guyot (Site 431) consist of a mixed material representing the "nondepositional" environment, including iron-manganese crusts. The specimens from Hole 432 on Nintoku guyot were taken from volcaniclastic sand on basalts and from a laterite soil layer between lava flows.

We have performed bulk silicate analyses, as well as sulfur and phosphorus determinations, on 26 samples by the X-ray fluorescence method, using the VRA-2 instrument (Tables 1 and 2); we used the Knopp device to determine $\mathrm{CaCO}_{3}$ and organic carbon. We used the atomic absorption method on 14 specimens to determine the contents of $\mathrm{Al}, \mathrm{Cr}, \mathrm{Zn}, \mathrm{Cu}, \mathrm{Ni}$, and $\mathrm{Co}$ (Table 3).

The authors are grateful to the Glomar Challenger Leg 55 scientists for taking the samples and making these materials available for our study.

\section{PELAGIC CALCAREOUS AND SILICEOUS- CALCAREOUS OOZES}

We have analyzed seven samples obtained from the most representative section recovered at Suiko guyot, Holes 433 and 433A. This series of samples contains slightly calcareous $\left(16 \% \mathrm{CaCO}_{3}\right)$ diatomaceous ooze (Sample 433A-4-2, 50-55 cm), siliceous-calcareous diatomaceous nannofossil oozes $\left(32-68 \% \mathrm{CaCO}_{3}\right)$, and highly calcareous nannofossil oozes $\left(75-76 \% \mathrm{CaCO}_{3}\right)$. The varying degrees of "dilution" with biogenic carbonate predetermine the bulk chemical compositions of the sediments (Table 1). To get rid of the "diluting" effect of carbonate we shall deal with paired ratios of the elements.

The values of the $\mathrm{SiO}_{2}$ to $\mathrm{Al}_{2} \mathrm{O}_{3}$ ratio, which in ordinary pelagic and hemipelagic clays range from 3 to 4 (on the average about 3.5), are found to be here much greater, and vary from 10 to 39 , except for the surface (upper Pliocene) layer of nannofossil-foraminiferal ooze, containing fewer radiolarians and diatoms, where it equals 4.5. Examination of smear slides has shown that in all the rest of the samples the high $\mathrm{SiO}_{2}$ to $\mathrm{Al}_{2} \mathrm{O}_{3}$ ratio is due to biogenic amorphous silica, principally to diatom frustules and their fragments. Calculation of the "excessive" content (in relation to the "average clay") of $\mathrm{SiO}_{2}$, after the formula suggested by $\mathrm{K}$. Boström (1976) $\left(\mathrm{SiO}_{2}{ }^{\mathrm{x}}=\mathrm{SiO}_{2}-3.5 \mathrm{Al}_{2} \mathrm{O}_{3}\right)$, shows the content of biogenic $\mathrm{SiO}_{2}{ }^{x}$ to be up to 54 per cent.

The Al to Ti ratio permits one to judge the nature of clastic and clayey matter in sediments. As revealed by K. Boström's studies (1976), this ratio in the ordinary pelagic sediments varies within a narrow range, close to the average one for continental crust (15) and shales (17.5). According to our data (Murdmaa et al., 1978), the $\mathrm{Al}$ to $\mathrm{Ti}$ ratio in terrigenous clay of the western North Atlantic is somewhat higher, and in most cases lies between 20 and 25 , i.e., close to the average for sedimentary rocks according to A. P. Vinogradov (1962), namely, 22.1. In the vitric tephra of the daciticrhyolitic composition, occurring in the Quaternary sediments of the northwestern Pacific in the form of "ash layers", this ratio, as an average from 35 analyses, (Repechka, 1974) is found to be 34.6 for narrow fluctuation ranges. Our analyses of tephra layers, volcanic 
TABLE 1

Bulk Composition (\% by X-ray fluorescence analyses) of the Leg 55 Sediments

\begin{tabular}{|c|c|c|c|c|c|c|c|c|c|c|c|}
\hline $\begin{array}{l}\text { Hole-Core-Section, } \\
\text { Interval }(\mathrm{cm})\end{array}$ & $\mathrm{SiO}_{2}$ & $\mathrm{TiO}_{2}$ & $\mathrm{Al}_{2} \mathrm{O}_{3}$ & $\mathrm{Fe}_{2} \mathrm{O}_{3}$ & $\mathrm{MnO}$ & $\mathrm{MgO}$ & $\mathrm{CaO}$ & $\mathrm{K}_{2} \mathrm{O}$ & $\mathrm{Na}_{2} \mathrm{O}$ & $\begin{array}{l}\text { Loss on } \\
\text { Ignition }\end{array}$ & $\mathrm{SiO}_{2} / \mathrm{Al}_{2} \mathrm{O}_{3}$ \\
\hline $430-2-3,55-64$ & 28.13 & 2.08 & 9.62 & 16.15 & 9.48 & 2.64 & 11.28 & 2.31 & 1.97 & 15.6 & 2.92 \\
\hline $430-2-3,70-78$ & 27.79 & 1.94 & 9.32 & 15.05 & 8.92 & 3.02 & 12.22 & 2.21 & 2.11 & 16.7 & 2.98 \\
\hline $430 \mathrm{~A}-1-1,30-34$ & 11.26 & 0.57 & 4.11 & 6.35 & 0.06 & 2.79 & 38.83 & 1.21 & 0.82 & 33.6 & 2.74 \\
\hline $430 \mathrm{~A}-2-1,104-108$ & 12.2 & 0.49 & 3.4 & 4.03 & 3.42 & 1.59 & 37.63 & 0.83 & 1.15 & 34.8 & 3.59 \\
\hline $430 \mathrm{~A}-4-1,74-78$ & 44.6 & 2.44 & 12.12 & 14.51 & 2.76 & 6.31 & 3.23 & 2.14 & 4.24 & 7.0 & 3.68 \\
\hline $431-1-1,69-78$ & 16.82 & 2.29 & 3.41 & 21.65 & 18.51 & 4.74 & 6.42 & 1.54 & 1.66 & 22.4 & 4.93 \\
\hline $431-2-1,2-7$ & 22.13 & 0.56 & 4.64 & 11.82 & 8.86 & 1.11 & 24.21 & 1.02 & 1.15 & 24.5 & 4.77 \\
\hline 431A-11, 99-104 & 36.00 & 0.81 & 7.50 & 12.01 & 12.75 & 2.54 & 8.86 & 1.52 & 2.39 & 15.1 & 4.74 \\
\hline $431 \mathrm{~A}-2-1,80-85$ & 41.20 & 1.46 & 10.38 & 13.81 & 2.44 & 3.55 & 7.78 & 2.08 & 2.96 & 14.3 & 3.97 \\
\hline $432-1-4,73-76$ & 36.85 & 1.01 & 7.28 & 18.2 & 0.05 & 3.35 & 11.88 & 2.80 & 2.95 & 15.4 & 5.06 \\
\hline $432 \mathrm{~A}-2, \mathrm{CC}(27-29)$ & 32.84 & 4.27 & 22.46 & 20.61 & 0.33 & 1.36 & 0.34 & 0.60 & 5.31 & 12.4 & 1.46 \\
\hline $433-1-1,70-72$ & 34.8 & 0.29 & 7.80 & 3.59 & 0.06 & 1.75 & 25.4 & 1.11 & 3.07 & 21.9 & 4.46 \\
\hline $433 \mathrm{~A}-1-1,30-35$ & 23.06 & 0.04 & 0.93 & 0.56 & 0.02 & 0.94 & 38.48 & 0.23 & 0.93 & 34.4 & 24.80 \\
\hline $433 \mathrm{~A}-3-1,32-36$ & 15.53 & 0.02 & 0.71 & 0.31 & 0.01 & 1.99 & 42.66 & 0.24 & 0.85 & 37.3 & 21.87 \\
\hline $433 \mathrm{~A}-3-4,53-59$ & 16.2 & 0.02 & 0.64 & 0.25 & 0.01 & - & 42.9 & 0.21 & 1.00 & 38.8 & 25.31 \\
\hline $433 \mathrm{~A}-4-2,50-55$ & 62.5 & 0.13 & 2.34 & 2.45 & 0.02 & 1.74 & 8.80 & 0.76 & 3.76 & 17.1 & 26.71 \\
\hline $433 \mathrm{~A}-5-1,110-114$ & 27.2 & 0.03 & 0.69 & 0.26 & 0.02 & 0.75 & 33.5 & 0.26 & 1.77 & 35.3 & 39.42 \\
\hline $433 \mathrm{~A}-6-7,44-46$ & 45.6 & 0.45 & 4.56 & 4.27 & 0.02 & 1.44 & 18.18 & 1.40 & 1.82 & 22.1 & 10.00 \\
\hline $433 \mathrm{~A}-9-6,30-31$ & 1.62 & 0.04 & 0.57 & 1.45 & 0.02 & 1.49 & 51.38 & 0.15 & 0.36 & 42.7 & 2.84 \\
\hline $433 \mathrm{~A}-10-1,89-94$ & 2.44 & 0.07 & 0.74 & 0.66 & 0.01 & 1.04 & 50.5 & 0.46 & 1.06 & 42.7 & 3.30 \\
\hline $433 \mathrm{~A}-12-1,76-78$ & 0.95 & 0.03 & 0.34 & 0.50 & 0.01 & 3.39 & 51.05 & 0.13 & - & 43.6 & 2.79 \\
\hline $433 \mathrm{~A}-14-1,70-76$ & 0.85 & 0.03 & 0.35 & 0.80 & 0.01 & 3.35 & 50.03 & 0.22 & 0.86 & 43.1 & 2.43 \\
\hline $433 \mathrm{~A}-16-1,52-56$ & 1.35 & 0.04 & 0.61 & 0.70 & 0.01 & 4.57 & 48.46 & 0.35 & 1.10 & 42.8 & 2.21 \\
\hline 433B-1-1, 36-42 & 1.32 & 0.04 & 0.50 & 0.42 & 0.01 & 3.04 & 50.17 & 0.32 & 1.13 & 42.9 & 2.64 \\
\hline 433B-2-1, 103-105 & 0.47 & 0.02 & 0.23 & 0.55 & 0.01 & 3.57 & 45.36 & 0.15 & 0.21 & 49.3 & 2.04 \\
\hline $433 C-3-3,103-109$ & 15.47 & 0.73 & 4.86 & 7.21 & 0.07 & 2.97 & 37.32 & 0.61 & 1.45 & 28.8 & 3.18 \\
\hline
\end{tabular}

Note: Total $\mathrm{Fe}$ is expressed as $\mathrm{Fe}_{2} \mathrm{O}_{3}$ including $\mathrm{FeO}$.

TABLE 2

Phosphorus and Sulfur Contents in the Leg 55 Sediments (X-ray fluorescence)

\begin{tabular}{|c|c|c|c|}
\hline \multirow{2}{*}{$\begin{array}{l}\text { Hole-Core-Section, } \\
\text { Interval }(\mathrm{cm})\end{array}$} & \multicolumn{2}{|c|}{ Wt. \% } & \multirow{2}{*}{$\begin{array}{l}\mathrm{Fe} / \mathrm{S} \\
\mathrm{Ratio}\end{array}$} \\
\hline & $\mathrm{P}_{2} \mathrm{O}_{5}$ & $\mathrm{~S}$ & \\
\hline $430-2-3,55-64$ & 0.91 & 0.13 & 85.3 \\
\hline $430-2-3,70-78$ & 0.97 & 0.17 & 60.5 \\
\hline $430 \mathrm{~A}-1-1,30-34$ & 1.56 & 0.13 & 33.1 \\
\hline $430 \mathrm{~A}-2-8,104-108$ & 1.14 & 0.08 & 115.0 \\
\hline $430 \mathrm{~A}-4-1,74-78$ & 0.16 & 0.05 & 196.0 \\
\hline $431-1-1,69-78$ & & 0.26 & 56.9 \\
\hline $431-2-1,2-7$ & 0.24 & 0.16 & 50.0 \\
\hline $431 \mathrm{~A}-1-1,99-104$ & 0.13 & 0.13 & 63.8 \\
\hline $431 \mathrm{~A}-2-1,80-85$ & 1.38 & 0.16 & 56.9 \\
\hline $432-1-4,73-76$ & 0.26 & 0.06 & 206.7 \\
\hline $433 \mathrm{~A}-5-1,110-114$ & 0.51 & 0.17 & 1.2 \\
\hline $433 \mathrm{~A}-6-7,44-46$ & 0.57 & 0.35 & 8.3 \\
\hline $433 A-9-6,30-31$ & 2.20 & 0.09 & 11.1 \\
\hline $433 \mathrm{~A}-10-1,89-94$ & 1.68 & 0.07 & 6.1 \\
\hline $433 \mathrm{~A}-12-1,76-78$ & 1.67 & 0.11 & 2.9 \\
\hline $433 \mathrm{~A}-14-1,70-76$ & 1.60 & 0.31 & 1.7 \\
\hline $433 \mathrm{~A}-16-1,52-56$ & 2.37 & 0.45 & 1.1 \\
\hline 433B-1-1, 36-42 & 1.55 & 0.31 & 0.9 \\
\hline 433B-2-1, 103-105 & 1.55 & 0.26 & 1.4 \\
\hline $433 \mathrm{C}-3-3,103-109$ & 1.68 & 0.11 & 44.4 \\
\hline
\end{tabular}

glasses, and pumice from the Indian Ocean (Svalnov et al., 1976) have revealed this ratio to be in most cases above 25 , maximally up to 60 .

K. Boström (1976) has found the average value of the $\mathrm{Al}$ to $\mathrm{Ti}$ ratio in basalts to be about 5. Our analyses of the altered volcaniclastic material of the alkaline-basaltic composition and of the clay formed after basalts from the base of the New England Seamounts in the Atlantic (Holes 382 and 385, Murdmaa et al., 1979) have revealed this value to be below 10 . In the alkaline basalts from Hole 433A, the $\mathrm{Al}$ to Ti ratio was found to be 3.9 or 4.0; in tholeiites of Hole $433 \mathrm{C}$ it ranges from 4.1 to 7.6 ; and in hawaiites from Hole 430A, it is from 4.3 to 5.2. Thus, the oceanic basaltic volcaniclastic matter must be marked in sediments by low $\mathrm{Al}$ to $\mathrm{Ti}$ values (from 4 to 8 ), and acidic tephra from island arc volcanoes, on the contrary, by high values (above 25 ).

As seen from Table 4, in the upper portion of the pelagic section (down to and including Core 433A-3) the $\mathrm{Al}$ to $\mathrm{Ti}$ values are high (24-38), and are related to the predominance of terrigenous clay and silt and andesitic belt volcaniclastics in aluminosilicate sedimentary matter. The low value (9) in Sample 433A-6-7, 44-46 cm points to the presence of a significant quantity of titanium-rich basaltic volcaniclastic matter, as evidenced, moreover, by examination of the smear slide (see Murd- 
TABLE 3

Trace Elements in the Leg 55 Sediments (atomic absorption analyses)

\begin{tabular}{|c|c|c|c|c|c|c|c|c|c|c|c|c|c|c|c|c|}
\hline \multirow{2}{*}{$\begin{array}{l}\text { Hole-Core-Section, } \\
\text { Interval }(\mathrm{cm})\end{array}$} & \multicolumn{3}{|c|}{$\%$} & \multicolumn{5}{|c|}{$\mathrm{ppm}$} & \multicolumn{8}{|c|}{$\times 10^{4}$} \\
\hline & $\mathrm{Al}$ & $\mathrm{Fe}$ & $\mathrm{Mn}$ & $\mathrm{Cr}$ & $\mathrm{Zn}$ & $\mathrm{Cu}$ & $\mathrm{Ni}$ & Co & $\mathrm{Cr} / \mathrm{Al}$ & $\mathrm{Zn} / \mathrm{Al}$ & $\mathrm{Cu} / \mathrm{Al}$ & $\mathrm{Ni} / \mathrm{Al}$ & $\mathrm{Co} / \mathrm{Al}$ & $\overline{\mathrm{Fe}+\mathrm{Mn}}$ & $\overline{\mathrm{Fe}+\mathrm{Mn}}$ & $\overline{\mathrm{Fe}+\mathrm{Mn}}$ \\
\hline $430 A-1-1,30-34$ & 2.40 & 4.44 & 0.05 & 110 & 80 & 43 & 90 & 28 & 46 & 33 & 18 & 38 & 12 & 10 & 20 & 6 \\
\hline $430 \mathrm{~A}-2-1,104-108$ & 2.07 & 2.82 & 2.63 & 17 & 112 & 15 & 40 & 7 & 8 & 54 & 7 & 19 & 3 & 3 & 7 & 1 \\
\hline $430 A-4-1,74-78$ & 7.72 & 10.16 & 2.12 & 108 & 198 & 34 & 107 & 56 & 14 & 26 & 4 & 14 & 7 & 3 & 9 & 5 \\
\hline $431-1-1,69-78$ & 1.82 & 15.16 & 14.25 & 12 & 570 & 520 & 5600 & 3740 & 7 & 313 & 286 & 3077 & 2055 & 18 & 190 & 127 \\
\hline $431 \mathrm{~A}-1-1,99-104$ & 4.50 & 8.41 & 9.82 & 90 & 420 & 240 & 1850 & 1520 & 20 & 93 & 53 & 411 & 338 & 13 & 101 & 83 \\
\hline $431 \mathrm{~A}-2-1,80-85$ & 6.50 & 9.67 & 1.88 & 110 & 300 & 168 & 570 & 150 & 17 & 46 & 26 & 88 & 23 & 15 & 49 & 13 \\
\hline $432-1-5,73-76$ & 5.45 & 12.74 & 0.39 & 690 & 188 & 29 & 108 & 47 & 127 & 34 & 5 & 20 & 9 & 2 & 8 & 4 \\
\hline 432A-2,CC (27-29) & 14.6 & 14.43 & 0.25 & 35 & 180 & 120 & 110 & 40 & 2 & 12 & 8 & 8 & 3 & 8 & 7 & 3 \\
\hline $433-1-1,70-72$ & 3.18 & 2.51 & 0.05 & 15 & 58 & 15 & 15 & 10 & 5 & 18 & 5 & 5 & 3 & 6 & 6 & 4 \\
\hline $433 \mathrm{~A}-1-1,30-35$ & 0.62 & 0.39 & 0.01 & 14 & 36 & 10 & 6 & 5 & 23 & 58 & 16 & 10 & 8 & 25 & 15 & 12 \\
\hline $433 A-3-4,53-59$ & 0.15 & 0.18 & 0.01 & 4 & 40 & 7 & 10 & 5 & 27 & 267 & 47 & 67 & 33 & 37 & 53 & - \\
\hline $433 \mathrm{~B}-1-1,36-42$ & 0.04 & 0.29 & 0.01 & 15 & 21 & 4 & 5 & 6 & 375 & 525 & 100 & 125 & 150 & 13 & - & 20 \\
\hline $433 \mathrm{~B}-2-1,103-105$ & 0.05 & 0.38 & 0.01 & 13 & 12 & 3 & 5 & 2 & 260 & 240 & 60 & 100 & 40 & 8 & 13 & 5 \\
\hline $433 C-3-3,103-109$ & 3.00 & 5.05 & 0.05 & 60 & 390 & 38 & 47 & 33 & 20 & 130 & 13 & 16 & 11 & 7 & 9 & 6 \\
\hline
\end{tabular}

TABLE 4

Interrelations Among Major Elements in the Leg 55 Sediments

\begin{tabular}{|c|c|c|c|c|c|c|c|c|}
\hline \multirow[b]{2}{*}{$\begin{array}{l}\text { Hole-Core-Section, } \\
\text { Interval }(\mathrm{cm})\end{array}$} & \multicolumn{4}{|c|}{ Elements (\%) } & \multicolumn{4}{|c|}{ Ratios } \\
\hline & $\mathrm{Ti}$ & $\mathrm{Al}$ & $\mathrm{Fe}$ & $\mathrm{Mn}$ & $\mathrm{Al} / \mathrm{Ti}$ & $\mathrm{Mn} / \mathrm{Fe}$ & $\mathrm{Fe} / \mathrm{Al}$ & $\frac{\mathrm{Al}_{2} \mathrm{O}_{3}}{\mathrm{MgO}}$ \\
\hline $430-2-3,55-64$ & 1.25 & 5.10 & 11.31 & 7.30 & 4.1 & 0.64 & 2.22 & 3.6 \\
\hline $430-2-3,70-78$ & 1.11 & 4.94 & 10.54 & 6.87 & 4.3 & 0.65 & 2.13 & 3.1 \\
\hline $430 \mathrm{~A}-1-1,30-34$ & 0.34 & 2.18 & 4.44 & 0.05 & 6.4 & 0.01 & 2.04 & 1.5 \\
\hline $430 \mathrm{~A}-2-1,104-108$ & 0.29 & 1.80 & 2.82 & 2.63 & 6.2 & 0.93 & 1.57 & 2.1 \\
\hline $430 \mathrm{~A}-4-1,74-78$ & 1.46 & 6.42 & 10.16 & 2.12 & 4.4 & 0.21 & 1.58 & 1.9 \\
\hline $431-1-1,69-78$ & 1.37 & 1.81 & 15.16 & 14.25 & 1.3 & 0.94 & 8.38 & 0.7 \\
\hline $431-2-1,2-7$ & 0.34 & 2.46 & 8.27 & 6.82 & 7.2 & 0.82 & 3.36 & 4.2 \\
\hline $431 \mathrm{~A}-1-1,99-104$ & 0.49 & 4.02 & 8.41 & 9.82 & 8.2 & 1.16 & 2.44 & 3.0 \\
\hline $431 \mathrm{~A}-2-1,80-85$ & 0.88 & 5.50 & 9.67 & 1.88 & 6.2 & 0.19 & 1.76 & 16.5 \\
\hline $432-1-4,73-76$ & 0.61 & 4.23 & 12.74 & 0.39 & 6.6 & 0.03 & 3.01 & 2.2 \\
\hline $432 \mathrm{~A}-2, \mathrm{CC}(27-29)$ & 2.56 & 11.90 & 14.43 & 0.25 & 4.6 & 0.02 & 1.21 & 16.5 \\
\hline $433-1-1,70-72$ & 0.17 & 4.13 & 2.51 & 0.05 & 24.3 & 0.02 & 0.61 & 4.5 \\
\hline $433 \mathrm{~A}-1-1,30-35$ & 0.02 & 0.49 & 0.39 & 0.01 & 24.5 & 0.02 & 0.80 & 1.0 \\
\hline $433 A-3-1,32-36$ & 0.01 & 0.38 & 0.02 & 0.01 & 38.0 & 0.04 & 0.05 & 0.4 \\
\hline $433 \mathrm{~A}-3-4,53-59$ & 0.01 & 0.36 & 0.18 & 0.01 & 34.0 & 0.06 & 0.50 & - \\
\hline $433 \mathrm{~A}-4-2,50-55$ & 0.08 & 1.24 & 1.78 & 0.02 & 15.5 & 0.01 & 1.44 & 1.3 \\
\hline $433 \mathrm{~A}-5-1,110-114$ & 0.02 & 0.37 & 0.18 & 0.02 & 18.5 & 0.11 & 0.49 & 0.9 \\
\hline $433 \mathrm{~A}-6-7,44-46$ & 0.27 & 2.42 & 2.99 & 0.02 & 9.0 & 0.01 & 1.24 & 3.2 \\
\hline $433 \mathrm{~A}-9-6,30-31$ & 0.02 & 0.30 & 1.02 & 0.02 & 15.0 & 0.02 & 3.40 & 0.4 \\
\hline 433A-10-1, 89-94 & 0.04 & 0.39 & 0.46 & 0.01 & 9.8 & 0.02 & 1.18 & 0.7 \\
\hline $433 \mathrm{~A}-12-1,76-78$ & 0.02 & 0.18 & 0.35 & 0.01 & 9.0 & 0.03 & 1.94 & 0.1 \\
\hline $433 \mathrm{~A}-14-1,70-76$ & 0.02 & 0.19 & 0.56 & 0.01 & 9.5 & 0.02 & 2.95 & 0.1 \\
\hline $433 \mathrm{~A}-16-1,52-56$ & 0.02 & 0.32 & 0.49 & 0.01 & 16.0 & 0.02 & 1.53 & 0.1 \\
\hline 433B-1-1, 36-42 & 0.02 & 0.26 & 0.29 & 0.01 & 13.0 & 0.03 & 1.12 & 0.2 \\
\hline 433B-2-1, 103-105 & 0.01 & 0.12 & 0.38 & 0.01 & 12.0 & 0.03 & 3.17 & 0.8 \\
\hline $433 \mathrm{C}-2-3,103-109$ & 0.44 & 2.58 & 5.05 & 0.05 & 5.9 & 0.01 & 1.96 & 1.6 \\
\hline
\end{tabular}

maa, Avdeiko, this volume). Samples from cores 4 and 5 have intermediate value.

The iron content is low, as is usual for pelagic biogenic sediments. The $\mathrm{Fe}$ to $\mathrm{Al}$ ratios in most cases were found to be below unity, but in two samples from Hole 433A (Cores 4 and 6) they are 1.4 and 1.2, respectively. In both samples, the sediments show a low carbonate content and a high content of biogenic silica. Furthermore, we observed a specific variation of radiolarians and diatoms in these samples: enrichment in large forms, with a coarse test in Sample 433A-4-2, 50-55 cm (we noted a sharp predominance of unbroken Coscinodiscus marginatus f. fossilis); a declining number of species; and a relatively insignificant content of fine detritus. Possibly, these peculiarities, as well as the relatively higher iron content, are related to decreased sedimentation rates caused by the effect of bottom currents. The currents are responsible for the selective washing-out of lightest particles from the sediments.
The Mn content is low, characterizing the sediments as hemipelagic, rather than truly pelagic. This conclusion is confirmed by the occurrence of pyrite, although it is rare.

Sulfur content in the two analyzed samples from Hole 433A, Cores 5 and 6 (Table 2), is apparently increased, and the $\mathrm{Fe}$ to $\mathrm{S}$ ratio is decreased, probably because of authigenic pyrite precipitation. The somewhat increased phosphorus content in both samples indicates a slightly phosphatization.

As for trace elements, zinc occurs in the highest concentrations. In one of the highly calcareous samples, the $\mathrm{Zn} / \mathrm{Al} \cdot 10^{4}$ ratio reached a value as high as 267 (Table $3)$. The other analyzed elements did not show any significant differences from the values which are common for pelagic calcareous sediments.

\section{SHALLOW-WATER BENTHOGENIC-DETRITAL SEDIMENTS}

The crushed benthogenic calcareous material is most abundant in the lowermost shallow-water interval on Suiko guyot (Site 433), where it occurs beneath the 52 -meter layer of pelagic sediments, and has been described as consisting of reef calcareous sand and sandy ooze with algal nodules (see "Lithostratigraphy"). We have analyzed some samples from this 110-meter-thick section (Hole 433A, Cores 9-16; Hole 433B, Cores 1 and 2), as well as a sample (from Section 433C-3-3) of reef calcareous sand lying between two lava flows which has been described as rich in basaltic volcaniclastic matter. Shallow-water benthogenic calcareous detritus, including the algal one, was found also in the upper cores from Sites 430, 431, and 432, but it is mixed up here with a significant quantity of volcaniclastic matter, authigenic iron-manganese crusts (having precipitated after guyot submergence) and ice-rafted clastic material.

Carbonate content in the shallow-water calcareous sediments from Site 433 is high - between 92.2 and 96.6 per cent by direct $\mathrm{CaCO}_{3}$ determinations - and only in the sediment lying between lava flows and enriched with volcaniclastic matter does it decrease to 60.7 per cent. Calculation of $\mathrm{CaO}$, as determined in the sili- 
cate analysis, on the $\mathrm{CaCO}_{3}$ basis yields slightly depressed values (80.7-91.5\%). Correspondingly reduced are the contents of all the other chemical elements, except for magnesium, which is largely associated with biogenic magnesian carbonates. The $\mathrm{Al}_{2} \mathrm{O}_{3}$ to $\mathrm{MgO}$ ratio (Table 4 ) is therefore sharply reduced (0.1-0.8), as compared with carbonate-free sediments and volcaniclastic matter, where it is always above unity. The $\mathrm{CaO}$ to $\mathrm{MgO}$ ratio, however, perceptibly declines only in the samples from the lower part of the section, where it varies from 11 to 15 , whereas Cores 9 and 10 (Hole 433A) yielded values which are common in pure calcite of pelagic sediments (above 40).

Low $\mathrm{SiO}_{2}$ to $\mathrm{Al}_{2} \mathrm{O}_{3}$ values (2.0-3.4) point not merely to a predominance of the volcaniclastic material of the basaltic composition in the non-calcareous sedimentary matter, but also to its alteration toward enrichment with aluminum, possibly owing to subaerial weathering.

Generally low A1:Ti ratio values (Table 4) furnish new evidence for the predominantly basaltic composition of non-biogenic sedimentary matter, but the very low concentrations of both titanium (close to the instrument sensitivity limit) and aluminum indicate that this criterion is not sufficiently trustworthy. It should be pointed out that the aluminum concentration, as determined by the atomic absorption method (Table 3 ), is in these samples much below that determined by the X-ray fluorescence method. This means that the true A1:Ti values can also be below those indicated in Table 4 .

The iron content in the high- $\mathrm{CaCO}_{3}$ sediments is naturally low, but calculations on the carbonate-free basis, and the Fe to A1 ratios (in every case above unity, maximally up to 3.4) and Fe to Ti ratios (maximally up to 51 ), brought to light a high iron content, pointing to the presence of a significant proportion of Fe forms unrelated to aluminosilicates. This is principally authigenic pyrite, numerous microscopic grains and microglobules of which are clearly visible in smear slides. Sulfur content in many samples is markedly increased (Table 2), confirming diagenetic pyrite precipitation. The Fe to $\mathrm{S}$ ratio ranges from 0.9 to 11.1 , except for Sample $433 \mathrm{C}$ $3-3,103-109 \mathrm{~cm}$, rich in iron-bearing volcaniclastic matter, where it is 47.4. The Mn contents and Mn to Fe ratios are low, corresponding to the reducing environment of early diagenesis.

All shallow-water calcareous sediments are more or less enriched in $\mathrm{P}_{2} \mathrm{O}_{5}$ (Table 2), apparently because of phosphatization of the biogenic carbonates, a widespread phenomenon on the Pacific guyots (Bezrukov et al., 1969; Baturin, 1978).

Two of the three analyzed samples from Hole 433B have revealed higher concentrations of trace elements (when calculated in terms of carbonate-free matter), and their higher ratio to A1 (Table 3). This ratio was observed to be particularly high for chromium and zinc, though also perceptibly high for the rest of the elements. Section 433C-3-3, which contains a great deal of volcaniclastic matter, was found to be enriched with zinc alone. Trace elements had presumably arrived into the sediments with organic matter. During its decomposition in the reducing environment, they were dissolved, and either isolated along with $\mathrm{Fe}$ into the sulfide phase or sorbed by the sediment.

\section{SEDIMENTS FORMED IN “NON-DEPOSITIONAL" ENVIRONMENT}

We have classed in this group the samples from the surface cores obtained at Sites 430 and 431 . Those from Site 430 contain mixed material comprising shallow-water calcareous detritus, ice-rafted pebbles, volcaniclastic matter, and fragments of iron-manganese crusts, as well as micronodules. From Hole 431 we have mostly crushed authigenic ferromanganese crusts with volcaniclastic matter and zeolites.

In the samples from Hole 430 and Core 430A-1, the $\mathrm{SiO}_{2}$ to $\mathrm{Al}_{2} \mathrm{O}_{3}$ ratio was low (2.7-3.0), below the average one for clay, and in the rest of the samples in this group it was found to be slightly higher (3.6-4.9). There is relatively much titanium, and the $\mathrm{Al}$ to $\mathrm{Ti}$ ratio is low, even in the samples where there is much aluminum, relative to silica (Table 4 ). The two ratios indicate the presence of volcaniclastic matter of basaltic composition, and partly to concentration of $\mathrm{Ti}$ in iron-manganese crusts, as is also observed in pelagic nodules from the Pacific Ocean (Skornyakova, 1976).

The high $\mathrm{Mn}$ and Fe contents, along with an increased Mn to Fe ratio, are characteristic features of the sediments, which contain abundant fragments of ferromanganese crusts. The ones richest in these crusts are Samples 431-1-1, 69-78 cm and 431A-1-1, 99-104 cm. The Fe content in these was found to be 15.2 and 8.4 per cent, respectively; Mn contents are 14.2 and 9.8 per cent, and the $\mathrm{Mn} / \mathrm{Fe}$ ratios are 0.94 and 1.16 respectively. The admixture of $\mathrm{CaCO}_{3}$ (as determined from $\mathrm{CaO}$ ) amounts to 11.4 and 15.8 per cent. The sum of $\mathrm{SiO}_{2}$ $+\mathrm{Al}_{2} \mathrm{O}_{3}$ (aluminosilicate matter) is 20 and 44 per cent, respectively. The first of these samples revealed a sharp increase in the $\mathrm{Ti}$ content $(1.4 \%)$. Both samples are rich in nickel and cobalt and less rich in zinc and copper.

In the other samples from Sites 430 and 431, the iron and manganese contents, as well as their ratios, vary within a wide range. The $\mathrm{Mn}$ to $\mathrm{Fe}$ ratios $(0.19-0.93)$ show that there occur both ferruginous crusts with low manganese content, and the typically iron-manganese crusts in which this ratio is approaching unity. Furthermore, it should be taken into account that we analyzed not the crusts or micronodules themselves but the sediments as a whole, in which iron is partly bound in silicates. The relatively high iron content of authigenic hydroxides is typical for the nodules and crusts from seamounts and peripheral oceanic regions (Skornyakova, 1976).

Most of the mixed sediments discussed herein show evidence of phosphatization. The $\mathrm{P}_{2} \mathrm{O}_{5}$ content (Table 2 ), however, in any of the analyzed samples does not reach the high values found in phosphatic rocks on midPacific and Emperor seamounts (Bezrukov et al., 1969; Baturin, 1978). Only a small portion of the phosphatic rocks may be present in the crushed and mixed-up material. 
To estimate the relative "saturation" of $\mathrm{Fe}$ and $\mathrm{Mn}$ hydroxides with trace elements, we have computed the ratio of the latter $\left(\times 10^{4}\right)$ to the sum of $\mathrm{Fe}+\mathrm{Mn}$ (Table 3 ). Comparing the figures thus obtained with those computed from N.S. Skornyakova's data (1976) for iron-manganese crusts and nodules in different regions of the Pacific, we have been convinced that the "saturation" with copper in all our samples was below the average values for the copper-poor nodules from seamounts $\left[\mathrm{Cu} \cdot 10^{4} /(\mathrm{Fe}+\mathrm{Mn})=39\right]$, for the hemipelagic sediments of the northwestern $\left[\mathrm{Cu} \cdot 10^{4} /(\mathrm{Fe}+\mathrm{Mn})=43\right]$ and northeastern $\left[\mathrm{Cu} \cdot 10^{4} /(\mathrm{Fe}+\mathrm{Mn})=22\right]$ peripheral regions of the ocean. The average relative nickel content $\left[\mathrm{Ni} \cdot 10^{4} /(\mathrm{Fe}+\mathrm{Mn})\right]$ in seamount nodules from the central part of the ocean was found to be 130; in the nodules on hemipelagic clay of the North Pacific the value averages 174; in the nodules on eupelagic clay of the North Pacific it is 214; and in the hemipelagic clay nodules it is 41 to 52 . In our two samples, from Sections 431-1-1 and 431A-1-1, which are the richest in $\mathrm{Fe}$ and Mn hydroxides, the "saturation" with nickel is thus quite significant, being comparable to that of seamount and miopelagic clay nodules.

The $\left[\mathrm{Co} \cdot 10^{4} /(\mathrm{Fe}+\mathrm{Mn})\right]$ ratio in nodules from seamounts is maximal, and averages 182; in the nodules on miopelagic clay of the northern Pacific it is 89 , and in the nodules on hemipelagic clay, 38 . The above two specimens of crushed iron-manganese crusts from Site 431 are, consequently, quite rich in cobalt, as is typical for ferruginous nodules on seamounts.

The low ratios of trace elements to $\mathrm{Fe}+\mathrm{Mn}$ in the other samples containing ferromanganese fragments result from the presence of a large quantity of $\mathrm{Fe}$ in the volcaniclastic material. In Section $431 \mathrm{~A}-2-1$, for instance, $\mathrm{Cu} \cdot 10^{4} /(\mathrm{Fe}+\mathrm{Mn})=89, \mathrm{Ni} \cdot 10^{4} /(\mathrm{Fe}+\mathrm{Mn})=$ 303 , and $\mathrm{Co} \cdot 10^{4} /(\mathrm{Fe}+\mathrm{Mn})=80$. For copper it is close to the average ratio for seamount nodules (70), for nickel it is higher than the average for seamount nodules (239), and for cobalt it is significantly below the average, not only in seamount nodules (331), but also in those of miopelagic clay (165), and is comparable to the very small ratio in hemipelagic clay nodules (98).

\section{LATERITE}

Lateritic soil, having formed at the time when, in place of Nintoku guyot, there was an island, is represented by sample $432 \mathrm{~A}-2$, CC $(27-29 \mathrm{~cm})$. Its chemical analysis (see Table 1) shows high concentrations of $\mathrm{Al}_{2} \mathrm{O}_{3}, \mathrm{Fe}_{2} \mathrm{O}_{3}$, and $\mathrm{TiO}_{2}$, and low concentrations of $\mathrm{SiO}_{2}, \mathrm{MnO}$, and $\mathrm{K}_{2} \mathrm{O}$, as is typical for subaerial weathering products of basic rocks. Correspondingly, the $\mathrm{SiO}_{2}: \mathrm{Al}_{2} \mathrm{O}_{3}$ and $\mathrm{Mn}: \mathrm{Fe}$ ratios are anomalously low. The $\mathrm{Al}$ :Ti ratios are close to those characteristic of the basalts from the same borehole, indicating a passive enrichment of laterite with iron, titanium, and aluminum, at the expense of $\mathrm{SiO}_{2}$ output.

The content of trace elements reveals some interesting shifts as compared with the basalts, as well as with palagonitized hyaloclastic matter characterizing the submarine weathering of basalts.
In the alkaline basalts above and below the laterite layer, the nickel content (as determined aboard ship) varies between 19 and 78 parts per million; in the hawaiites from Hole 430A, the Ni concentration is even lower (12-20 ppm), but in Hole 433, according to the same determinations, the alkaline basalts are richer in nickel (47-186 ppm). The value we obtained for laterites, $110 \mathrm{ppm}$, presumably indicates, nonetheless, enrichment with nickel during lateritization. In submarine palagonitization this was not observed; rather, nickel depletion is taking place (Kashintsev, 1975).

In the basalts from Hole $315 \mathrm{~A}$ in the Mid-Pacific Seamounts (Jackson et al., 1976), the cobalt content ranges between 44 and 56 parts per million and the copper content between 70 and 100 parts per million. Similar values are characteristic for the Hawaiian tholeiites and alkaline basalts (Hubbard, 1967). Our values in the laterite -40 and 120 parts per million - do not reveal any significant deviations. The low concentration of chromium (35 ppm) is significantly below the average values for the basalts from Hole 315A (108-121) and those for the Hawaiian alkaline basalts (433) and tholeiites (567). Apparently, the lateritization of basalts in an oxidizing environment is accompanied by leaching of chromium. In submarine palagonitization, no such phenomenon has been noted, but we found it in the alteration products of the basaltic volcaniclastic matter of the Cretaceous in cores from Holes 382 and 385 on the New England seamounts in the Atlantic (Murdmaa et al., 1979).

We have no data on the $\mathrm{Cu}$ and $\mathrm{Zn}$ contents of the Nintoku guyot basalts, but the values obtained for the laterite do not go beyond those for the basaltic rocks of the Hawaiian Islands.

All of the studied trace-element-to-aluminum ratios are low, presumably because of the high concentrations of aluminum.

\section{CONCLUSIONS}

Despite a limited number of analyzed samples, we have succeeded in bringing to light certain geochemical features of sediments on the Emperor Seamounts, related both to their sedimentation and their diagenesis. The Neogene pelagic (hemipelagic?) calcareous sediments (Site 433) are rich in biogenic silica, thus reflecting the sedimentation environment in the Boreal silicaaccumulation belt. Prominent among them are the layers with an $\mathrm{Fe}$ content high in relation to the content of non-biogenic sedimentary matter (the latter's index is $\mathrm{Al}$ ), presumably associated with a slowdown of sedimentation resulting from strong bottom currents. High $\mathrm{A} 1: \mathrm{Ti}$ ratios point to the absence, in the majority of samples, of an admixture of basaltic volcaniclastic matter.

The other types of sediments, on the other hand, contain basaltic matter reducing the $\mathrm{SiO}_{2}: \mathrm{Al}_{2} \mathrm{O}_{3}$ and particularly the $\mathrm{A} 1$ :Ti ratios. Biogenic silica in Paleogene shallow-water calcareous sediments is nonexistent. Lying buried beneath pelagic sediments, these sediments have retained the features of a reducing environment of 
early diagenesis, and a relative enrichment with iron in the form of pyrite and siderite (?), as well as with zinc and chromium.

Authigenic ferromanganese crusts, having formed on guyots under a prolonged "non-depositional" environment, are chemically close to the ferromanganese nodules of the Pacific's peripheral regions and seamounts: they are relatively rich in iron, nickel, and cobalt, but contain little copper.

The shallow-water calcareous sediments are somewhat phosphatized, but we have not found any phosphoritic rocks comparable to those dredged from MidPacific and Emperor chain guyots (Bezrukov et al., 1969; Baturin, 1978).

The chemical features of laterite prove its affinity to basalts and enable it to be distinguished from the submarine weathering products of basaltic hyaloclastic matter.

\section{REFERENCES}

Baturin, G. N., 1978. Phosphorites on the Ocean Bottom: Moscow (Publ. House “Nauka”), p. 229. (In Russian.)

Bezrukov, P. L., Andrushchenko, P. F., Murdmaa, I. O., Skornyakova, N. S., 1969. Phosphorites of the Central Pacific, Dokl. Acad. Nauk SSSR, v. 185, pp. 913-916. (In Russian.)

Boström, K., 1976. Particulate and dissolved matter as sources for pelagic sediments, Stockholm Contributions in Geology, v. XXX: 2. Stockholm (Almqvist and Wiksell), pp. 15-77.
Hubbard, N. J., 1967. Some trace elements in Hawaiian lavas: Ph.D. thesis, University of Hawaii, 128 pp.

Jackson, E. D., Bargar, K. E., Fabbi, B. P., and Heropoulous, C., 1976. Petrology of the basaltic rocks drilled on Leg 33 of the Deep Sea Drilling Project. In Schlanger, S. O., Jackson, E. D., et al. Initial Reports of the Deep Sea Drilling Project, v. 33: Washington (U. S. Government Printing Office), pp. 571-630.

Kashintsev, G. L., 1975. Petrochemical and geochemical features of palagonitized basalt alteration in the deep-sea environment, Oceanologya, v. XV, no. 2, pp. 282-288. (In Russian.)

Murdmaa, I. O., Gordeev, V. V., Bazilevskaya, E. S., Emelyanov, E. M., 1979. Inorganic geochemistry of the Leg 43 sediments. In Tucholke, B. E., Vogt, P. R., et al. Initial Reports of the Deep Sea Drilling Project, v. 43: Washington (U. S. Government Printing Office), pp. 675-694.

Repechka, M. A., 1974. Ash layers in bottom sediments of the Asia-Pacific transition zone. In Geological and Geophysical Problems of the Northwestern Pacific Marginal Seas: Vladivostok (Far Eastern Science Centre, USSR Acad. Sci.), pp. 26-42. In Russian.

Skornyakova, N. S., 1976. Chemical composition of ferromanganese nodules of the Pacific. In Bezrukov, P. L. (Ed.), Ferromanganese Nodules of the Pacific Ocean: Moscow (Publ. House "Nauka", p. 190. (In Russian.)

Svalnov, V. N., Murdmaa, I. O., Repechka, M. A., Demidenko, E. L., 1976. Volcanic matter in Quaternary sediments in the eastern Indian Ocean, Oceanologya, v. XVI, no. 3, pp. 479-487.

Vinogradov, A. P., 1962. Average concentrations of elements in main magmatic rocks of the Earth's crust, Geochimia, no. 7 , p. 555. (In Russian.) 